\title{
Combinations of herbs and probiotics as an alternative growth promoter: An in vitro study
}

\author{
Vinsa Cantya Prakasita ${ }^{1}$, Widya Asmara², Sitarina Widyarini ${ }^{3}$ and Agnesia Endang Tri Hastuti Wahyuni ${ }^{2}$
}

1. Study Program of Sains Veteriner, Faculty of Veterinary Medicine, Universitas Gadjah Mada, Yogyakarta 55281, Indonesia; 2. Department of Microbiology, Faculty of Veterinary Medicine, Universitas Gadjah Mada, Yogyakarta 55281, Indonesia; 3. Department of Pathology, Faculty of Veterinary Medicine, Universitas Gadjah Mada, Yogyakarta 55281, Indonesia.

Corresponding author: Agnesia Endang Tri Hastuti Wahyuni, e-mail: wahyuni_aeth@yahoo.com

Co-author: VCP: vinsa.cantya.p@mail.ugm.ac.id, WA: wied as@yahoo.co.uk, SW: sitarina@ugm.ac.id Received: 02-12-2018, Accepted: 11-03-2019, Published online: 30-04-2019

doi: 10.14202/vetworld.2019.614-620 How to cite this article: Prakasita VC, Asmara W, Widyarini S, Wahyuni AETH (2019) Combinations of herbs and probiotics as an alternative growth promoter: An in vitro study, Veterinary World, 12(4): 614-620.

\begin{abstract}
Background and Aim: Antibiotic growth promoters (AGPs) are added to animal feed to stimulate growth and increase livestock productivity. However, the regular use of antibiotics in animal diets has a considerable contribution to the occurrence of antibiotic resistance in livestock and humans. This study aimed to investigate the feasibility of red ginger (Zingiber officinale var. Rubrum), turmeric (Curcuma domestica), and wild ginger (Curcuma xanthorrhiza), Lactobacillus acidophilus, and Lactobacillus brevis as an alternative to AGPs.
\end{abstract}

Materials and Methods: The antibacterial activities and probiotic stimulatory effects of herbs were screened through the disk diffusion method and optical densitometry. The inhibitory ability of probiotics against pathogens was also tested through the disk diffusion method. The adhesion ability of probiotics was tested by mixing the optimal herbal combinations with broiler intestinal epithelial cells $\left(10^{5}\right.$ cells $\left./ \mathrm{ml}\right)$. The cells were then subjected to Gram staining, and the number of adherent bacteria was calculated.

Results: The test results showed that 3.13\% ethanolic wild ginger extract had the highest inhibitory activity against Salmonella Enteritidis, followed by ethanolic red ginger extract and aqueous wild ginger extract at the same concentration. The three extracts also supported the growth of L. acidophilus and L. brevis. Further tests showed that the combination of $3.13 \%$ ethanolic red ginger extract had the highest inhibitory activity against $S$. Enteritidis, followed by ethanolic and aqueous wild ginger extract at the same concentration. The three extracts also supported the growth of L. acidophilus and L. brevis. Further tests showed that the combination of 3.13\% ethanolic red ginger extract and 3.13\% aqueous wild ginger extract had the best inhibitory effect on the growth of $S$. Enteritidis. The stimulatory effect of the combinations of herbal extract on the growth of $L$. acidophilus $(0.18 \pm 0.00)$ and L. brevis $(0.21 \pm 0.01)$ was better than those of individual extract, positive controls, and the glucose control. L. acidophilus and L. brevis had a weak inhibitory effect on the growth of $S$. Enteritidis $(<6 \mathrm{~mm})$. The adhesion ability of L. acidophilus $(420.00 \pm 28.21)$ and L. brevis $(259.33 \pm 24.03)$ was stronger than that of $S$. Enteritidis $(202.00 \pm 14.00)$ under treatment with combined extracts.

Conclusion: The tested combinations of herbs and probiotics can adhere to the intestinal tract. Given this characteristic, herb and probiotic combinations may be developed as an alternative to conventional AGPs.

Keywords: antibiotic growth promoter, feed additive, herbs, probiotic.

\section{Introduction}

Antibiotic growth promoters (AGPs) are widely added to animal feed to stimulate growth, rapidly increase productivity, and minimize mortality by preventing infections [1]. The use of AGP has a drastic effect on the development and occurrence of antibiotic resistance in animals and humans [2-4]. The World Health Organization and the World Organization for Animal Health have encouraged the health, agriculture, and veterinary sectors to reduce the injudicious use of AGPs [5].

Copyright: Prakasita, et al. Open Access. This article is distributed under the terms of the Creative Commons Attribution 4.0 International License (http://creativecommons.org/licenses/ by/4.0/), which permits unrestricted use, distribution, and reproduction in any medium, provided you give appropriate credit to the original author(s) and the source, provide a link to the Creative Commons license, and indicate if changes were made. The Creative Commons Public Domain Dedication waiver (http:// creativecommons.org/publicdomain/zero/1.0/) applies to the data made available in this article, unless otherwise stated.
One of the solutions for reducing the use of AGPs is to explore and develop the biodiversity of natural resources of growth promoters. Natural rhizomes such as ginger, turmeric, and wild ginger have numerous beneficial pharmacological effects, such as antimicrobial, anti-inflammatory, antioxidant, anticancer, immunostimulatory, and immunomodulatory effects [6]. The members of Lactobacillus genus are the dominant normal microflora in the poultry digestive tract. Lactobacillus acidophilus and Lactobacillus brevis are the major species of lactic acid bacteria that provide numerous benefits to poultry health [7].

The utilization of a combination of herbs and probiotics as functional feeds has not been widely studied. Although individual herbs and probiotics are highly valuable, their combinations may enhance their effectiveness and usefulness through synergism. This study aimed to investigate the feasibility of red ginger (Zingiber officinale var. Rubrum), turmeric (Curcuma 
domestica), and wild ginger (Curcuma xanthorrhiza), L. acidophilus, and L. brevis as an alternative to AGPs.

\section{Materials and Methods}

\section{Ethical approval}

The Ethics Committee of Universitas Gadjah Mada (UGM), Yogyakarta, Indonesia, has declared that this work satisfies ethical requirements (number: 23.04/III/UN1/LPPT/2018).

\section{Pathogen and probiotics}

The pathogen, Salmonella Enteritidis B2664, was obtained from the collection of the Center for Veterinary Research (Bbalitvet, Bogor, Indonesia) and used to evaluate the inhibitory effect of different herbs. S. Enteritidis B2664 was isolated from the chicken intestines collected from Bogor Tengah district, Bogor Regency, West Java, Indonesia. The probiotics, L. acidophilus FNCC 0051 and L. brevis FNCC 0021, were obtained from the collection of UGM Inter-University Center (PAU, Yogyakarta, Indonesia). The pathogens were cultured in Broth Heart Infusion Media (BHI; Merck ${ }^{\mathrm{TM}}$ ), incubated at $37^{\circ} \mathrm{C}$ for $24 \mathrm{~h}[8,9]$. L. acidophilus and L. brevis were cultured on de Man-Rogosa Sharpe broth media (MRS; Merck ${ }^{\mathrm{TM}}$ ), incubated at $37^{\circ} \mathrm{C}$ for $24 \mathrm{~h}$ under $\mathrm{CO}_{2}$-enriched condition $[7,10]$.

\section{Herb extract}

Rhizomes of red ginger ( $Z$. officinale var. Rubrum), turmeric ( $C$. domestica), and wild ginger (C. xanthorrhiza) were used in this study. The rhizomes were extracted using $96 \%$ ethanol and water.

\section{$\mathbf{9 6 \%}$ Ethanolic extracts}

Ethanolic extract of red ginger, turmeric, and wild ginger was obtained from the Department of Pharmaceutical Biology, Faculty of Pharmacy, UGM. Extraction was performed through the maceration extraction method. Extracts were prepared at seven different concentrations $(100 \%, 50 \%, 25 \%, 12.5 \%$, $6.25 \%, 3.125 \%$, and $1.67 \%$ ).

\section{Aqueous extracts}

Dry form of red ginger, turmeric, and ginger were obtained from the Department of Pharmaceutical Biology, Faculty of Pharmacy, UGM. Extraction was prepared by adding sterile distilled water $(25 \% \mathrm{w} / \mathrm{v})$ to dry of rhizomes. The extracts were then stored for $24 \mathrm{~h}$ with occasional stirring. The suspensions were centrifuged for $5 \mathrm{~min}$ at the speed of 10,000 rpm [11]. Extracts were prepared at five different concentrations $(25 \%, 12.5 \%, 6.25 \%, 3.125 \%$, and $1.67 \%)$.

\section{Determination of antibacterial activities and stimu- latory effects \\ Diffusion disk test}

A modified Kirby-Bauer diffusion disk method was performed to assay the antibacterial activities against pathogens and the stimulatory effects on probiotic growth exerted by the herbs [12]. Suspensions of $S$. Enteritidis and Lactobacillus were spread on Mueller Hinton Agar (MHA; Merck ${ }^{\mathrm{TM}}$ ) and MRS $\left(\right.$ Merck $\left.^{\mathrm{TM}}\right)$, respectively, at a density of $1.5 \times 10^{8}$ colony-forming unit per milliliter (CFU/mL) [13]. $20 \mu \mathrm{L}$ of herbal extract was individually added to blank disks $\left(\right.$ Oxoid $\left.^{\mathrm{TM}}\right)$ which were then placed on the surfaces of

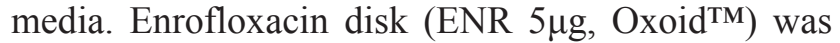
used as positive controls. A disk treated with sterile distilled water was used as negative control. Culture media were incubated at $37^{\circ} \mathrm{C}$ for $24 \mathrm{~h}$ (under $\mathrm{CO}_{2}$ enriched conditions for Lactobacillus growth). The diameter of each zone after incubation was measured in millimeters. The clear zone surrounding the disk was used as an index of herbal antibacterial activity against pathogens, whereas the growth zone around the disk represented the ability of herbal extracts to support bacterial growth. All tests were conducted in triplicate.

\section{Optical density (OD) test}

The minimum inhibitory concentration against $S$. Enteritidis and the maximum growth-promoting concentration for L. acidophilus and L. brevis of the optimal extracts were determined through the broth microdilution technique in accordance with the Clinical and Laboratory Standards Institute M07A9 [14] and Clinical Institute Standard Institute M11A8 [15] with minor modifications. The best herbal extracts were prepared in the first well. Then, twofold dilutions of samples were prepared with the concentration range $1.56-25 \%$ in $96-$-well microplates. $10 \mu \mathrm{L}$ of bacterial suspensions with a concentration of $1.5 \times 10^{8} \mathrm{CFU} / \mathrm{mL}$ was added into each well. Broth media without extracts were used as the negative controls. Cultured broth media were used as positive controls. The growth of probiotics in different media was compared with that in $1 \%$ glucose medium [16]. Microplate was incubated at $37^{\circ} \mathrm{C}$ for $24 \mathrm{~h}$ (under $\mathrm{CO}_{2}$-enriched conditions for Lactobacillus growth). The OD of culture media was determined with a microplate reader $(655 \mathrm{~nm})$. The test was performed in triplicate.

\section{Test of the inhibitory effect of $L$. acidophilus and} L. brevis against $S$. Enteritidis

The well diffusion method performed by Son et al. [17] and Chakraborty and Bhowal [18] was used in this test with modifications. $S$. Enteritidis $\left(1.5 \times 10^{8}\right.$ $\mathrm{CFU} / \mathrm{ml}$ ) was cultured on MHA media through the pour method. Each well was filled with $20 \mu \mathrm{L}$ aliquots of L. acidophilus $\left(10^{6} \mathrm{CFU} / \mathrm{ml}\right)$, L. brevis $\left(10^{6} \mathrm{CFU} / \mathrm{ml}\right)$, or $1: 1$ mixture of L. acidophilus $\left(10^{6}\right.$ $\mathrm{CFU} / \mathrm{ml})$ and $L$. brevis $\left(10^{6} \mathrm{CFU} / \mathrm{ml}\right)$. Enrofloxacin disks (ENR $5 \mu \mathrm{g}$, Oxoid ${ }^{\mathrm{TM}}$ ) were used as positive controls. Media were incubated at $37^{\circ} \mathrm{C}$ for $24 \mathrm{~h}$. The diameter of the inhibition zone (DIZ, $\mathrm{mm}$ ) was measured after incubation.

\section{Adhesion test}

The adhesion ability of L. acidophilus, L. brevis, and $S$. Enteritidis was tested through a method presented by Abdulla et al. [19] with modifications. The intestinal epithelial cells of 14-21-week-old broilers 
(Gallus gallus domesticus) were used in this test. Epithelial cells were scraped from the ileum and cecum using a spatula and suspended in $5 \mathrm{ml}$ of phosphate-buffered saline ( $\mathrm{pH} 7.4$, Sigma-Aldrich ${ }^{\mathrm{TM}}$ ). The suspension was centrifuged at $1000 \mathrm{rpm}$ for $10 \mathrm{~min}$ and washed twice using the same method. Epithelial cells were counted with a hemocytometer to ensure that solutions had cell concentrations of $10^{5}$ cells $/ \mathrm{ml}$.

The adhesion test was performed as follows: First, epithelial cells and bacterial suspensions $\left(1.5 \times 10^{8} \mathrm{CFU} / \mathrm{ml}\right)$ were mixed at the same volume in $1 \%$ herbal combination solution and then incubated at room temperature for $60 \mathrm{~min}$. Bacteria that did not adhere to epithelial cells were separated from the suspensions through centrifugation at $2000 \mathrm{rpm}$ for $10 \mathrm{~min}$. The suspension was washed twice at the same speed. Pellets were fixed on glass slides with methanol and stained using Gram stain. The adhesion index was determined by calculating the number of probiotic bacteria that had attached to 50 epithelial cells.

\section{Statistical analysis}

The data from the disk diffusion test were analyzed through one-way analysis of variance and post hoc Tukey test. The results of OD determination were analyzed through the Kruskal-Wallis and Mann-Whitney tests, whereas adhesion test data were descriptively analyzed. Differences between means were considered statistically significant when $\mathrm{p}<0.05$.

\section{Results}

\section{Antibacterial activities of herbal extracts}

The DIZs surrounding colonies of $S$. Enteritidis under treatment with the ethanolic and aqueous extracts of red ginger extract, turmeric, wild ginger, and their combination were measured in millimeters. The results are shown in Table-1. The highest inhibitory activity against $S$. Enteritidis $(21.33 \pm 0.58 \mathrm{~mm})$ was exerted by the ethanolic wild ginger extract, followed by ethanolic red ginger extract $(14.33 \pm 0.58 \mathrm{~mm})$, ethanolic turmeric extract $(8.33 \pm 0.58 \mathrm{~mm})$, and aqueous wild ginger extract $(8.00 \pm 0.58 \mathrm{~mm})$. Aqueous red ginger extract and aqueous turmeric extract demonstrated weak inhibitory activities $(<6 \mathrm{~mm})$. The positive control, enrofloxacin, presented antibacterial activity, as indicated by the presence of an inhibition zone $(12 \pm 0.00 \mathrm{~mm})$. By contrast, distilled water, which was used as the negative control, did not show antibacterial activity.

The extracts with moderate $(6-11 \mathrm{~mm})$ and moderate-to-high antibacterial activity $(>11 \mathrm{~mm})$ were further tested through the determination of the OD value of bacterial growth in liquid media enriched with $1 \%$ extract (Table-2). The turbidity of the liquid culture wild ginger extract or 3.13-25\% aqueous wild ginger extract did not increase. The OD of the liquid culture of $S$. Enteritidis enriched with $1.56-25 \%$ ethanolic

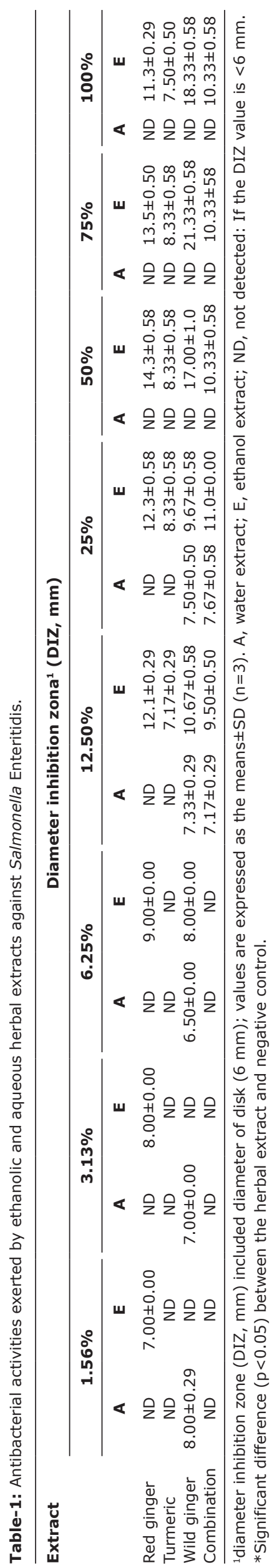

Veterinary World, EISSN: 2231-0916 
Table-2: Growth of Salmonella Enteritidis in media enriched with herbal extracts.

\begin{tabular}{lcccccc}
\hline \multirow{2}{*}{ Extract } & \multicolumn{3}{c}{ Optical density (655 nm) } & \multirow{2}{*}{ Positive control } \\
\cline { 2 - 6 } & $\mathbf{1 . 5 6 \%}$ & $\mathbf{3 . 1 3} \%$ & $\mathbf{6 . 2 5} \%$ & $\mathbf{1 2 . 5 \%}$ & $\mathbf{2 5 \%}$ & \\
\hline Red ginger ethanol extract & $0.07 \pm 0.02^{\mathrm{a}}$ & $0.00 \pm 0.00^{\mathrm{a}}$ & $0.00 \pm 0.00^{\mathrm{a}}$ & $0.00 \pm 0.00^{\mathrm{a}}$ & $0.00 \pm 0.00^{\mathrm{a}}$ & $0.14 \pm 0.01$ \\
Wild ginger ethanol extract & $0.00 \pm 0.00^{\mathrm{a}}$ & $0.00 \pm 0.00^{\mathrm{a}}$ & $0.00 \pm 0.00^{\mathrm{a}}$ & $0.00 \pm 0.00^{\mathrm{a}}$ & $0.00 \pm 0.00^{\mathrm{a}}$ & $0.14 \pm 0.01$ \\
Wild ginger water extract & $0.14 \pm 0.01$ & $0.00 \pm 0.00^{\mathrm{a}}$ & $0.00 \pm 0.00^{\mathrm{a}}$ & $0.00 \pm 0.00^{\mathrm{a}}$ & $0.00 \pm 0.00^{\mathrm{a}}$ & $0.14 \pm 0.01$ \\
\hline
\end{tabular}

aSignificant difference $(\mathrm{p}<0.05)$ between the herbal extract and positive control.

of $S$. Enteritidis enriched with $1.56 \%$ aqueous wild ginger extract increased to $0.14 \pm 0.01$, which is the same that of the positive control. The culture media enriched with $3.13-25 \%$ ethanolic red ginger extract exhibited antibacterial activity against $S$. Enteritidis as evidenced by the lack of an increase in OD value. The OD of the cultured media enriched with $1.56 \%$ ethanolic red ginger extract, however, increased $(0.07 \pm 0.02)$. This increase was not significant because the value was significantly different from that of the positive control $(0.14 \pm 0.01)$.

\section{Growth stimulatory activities of herbal extracts toward probiotic bacteria}

Treatment with ethanolic and aqueous herbal extract did not result in the formation of an inhibition zone around $L$. acidophilus and $L$. brevis colonies. The diameters of the growth zones of each probiotic species around the ethanolic and aqueous extract disks could not be measured because probiotics did not grow with rounded forms. The OD value of $L$. acidophilus culture in MRS broth media enriched with all herbal extracts was higher than those of the positive control (Table-3). The OD value of the growth media enriched with $1.56-6.25 \%$ ethanolic red ginger extract, $1.56 \%$ ethanolic wild ginger extract, and $1.56 \%$ and $6.25 \%$ aqueous wild ginger extract was significantly different $(p<0.05)$ from that of the positive and glucose controls. The OD value of the growth media enriched with $12.5 \%$ ethanolic red ginger extract, $3.13-12.5 \%$ ethanolic wild ginger extract, and $3.13 \%$ and $12.5 \%$ aqueous wild ginger extract was significantly different from that of the positive control $(p<0.05)$ but was lower than those of the glucose control. On average, the growth of probiotic bacteria in media enriched with $25 \%$ herbal extracts was lower than that of probiotic bacteria grown in media enriched with other concentrations of herbal extracts and glucose control.

The OD value of $L$. brevis grown in media enriched with $1 \%$ herbal extract is presented in Table- 4 . The OD value of media enriched with 1.56-12.5\% ethanolic red ginger extract, ethanolic wild ginger extract, and aqueous wild ginger extract was greater than those of the positive and glucose controls. Growth media enriched with $6.25 \%$ ethanolic red ginger extract showed the highest OD value and significantly superior stimulatory effects on the growth of L. brevis $(\mathrm{p}<0.05)$ than the positive and glucose controls. However, the OD values of media enriched with $25 \%$ herbal extracts were lower than those of the control.
Growth stimulatory activities of the combination of herbal extracts toward pathogens and probiotics

Previous test results showed that $3.13 \%$ ethanolic red ginger extract, $3.13 \%$ ethanolic wild ginger extract, and $3.13 \%$ aqueous wild ginger extract are the optimal extracts for inhibiting the growth of $S$. Enteritidis and for stimulating the growth of L. acidophilus and L. brevis. The extracts were divided into two extract combinations: Extract combination 1, which comprised ethanolic red ginger and wild ginger extracts, and extract combination 2, which comprised ethanolic red ginger and aqueous wild ginger extracts.

The cultures of L. acidophilus and L. brevis in media enriched with extract combination 1 and 2 showed the highest OD values (Table-5). Extract combination 2 was able to support the growth of L. acidophilus and L. brevis and also had better antibacterial activity against $S$. Enteritidis than extract combination $1(\mathrm{p}<0.05)$. These results demonstrate that herbal extracts can stimulate the growth of probiotics and have antibacterial activity against pathogens as mentioned by Zhou et al. [20] and Zadeh and Kor [21].

\section{Inhibitory activities of $L$. acidophilus and $L$. brevis against $S$. Enteritidis}

Probiotics and their combinations exerted a weak inhibitory effect on $S$. Enteritidis, as indicated by the presence of a DIZ of $<6 \mathrm{~mm}$.

Adhesion ability of $L$. acidophilus, $L$. brevis, and S. Enteritidis to intestinal epithelial cells

An adhesion test was conducted to determine the adhesion ability of L. acidophilus, L. brevis, and $S$. Enteritidis to the intestinal epithelial cells of broilers. The adhesion ability of each bacterial isolate to epithelial cells is presented in Table-6. The adhesion ability of each bacterial species differed. The highest adhesion ability was exhibited by L. acidophilus (Figure-1), followed by L. brevis and $S$. Enteritidis.

\section{Discussion}

Ethanolic wild ginger extract (1.56-25\%) exhibited the highest inhibitory activity against $S$. Enteritidis, followed by ethanolic red ginger (3.13$25 \%)$ and aqueous wild ginger (3.13-25\%) extracts. Wild ginger extract contains xanthorrhizol (XNT), an antimicrobial terpenoid compound that is absent from other Curcuma rhizomes [22]. Although the exact mechanism underlying the antimicrobial activity of XNT remains unclear, the suppression of nuclear 


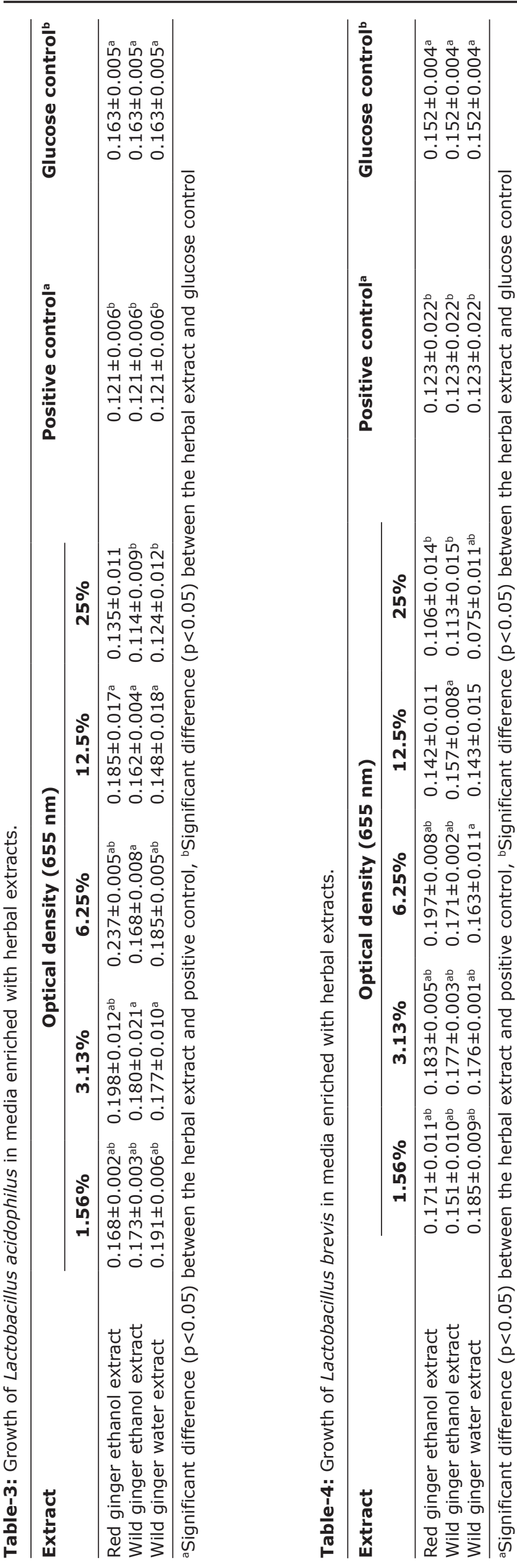

factor kappa-B (NF-kB) and mitogen-activated protein kinase (MAPK) by XNT will stimulate immune responses [23]. XNT may account for higher inhibitory power of wild ginger than that of turmeric and red ginger. The essential oils, gingerol and zingiberene, which are phenol derivatives, are the main antimicrobial compounds of red ginger [24,25]. Test results showed that the antibacterial activity of extracts with an ethanolic base is better than that of extracts with an aqueous base because the antibacterial compounds present in ethanolic extracts are more exposed than those in aqueous extracts [26].

The extracts were able to support the growth of L. acidophilus and L. brevis, and all three extracts inhibited S. Enteritidis growth. Zhou et al. [20] and Molan et al. [27] reported that polyphenols in herbal extracts exert their high antioxidant activity against free radicals and oxidative stress generated by metabolic activity by providing a microaerophilic environment for the growth of probiotic bacteria. In addition, the carbohydrate content of herbal extract can be a good substrate for probiotic growth [28]. Further tests showed that the combination of $3.13 \%$ ethanolic red ginger extract and $3.13 \%$ aqueous wild ginger extract had an inhibitory effect on $S$. Enteritidis $(0.00 \pm 0.00)$ and had better growth-stimulating effects on L. acidophilus $(0.18 \pm 0.00)$ and $L$. brevis $(0.21 \pm 0.01)$ than individual extracts and positive and the glucose controls.

L. acidophilus, L. brevis, and even the combination of both bacteria had a weak inhibitory effect on $S$. Enteritidis $(<6 \mathrm{~mm})$. Son et al. [17] and Fuller [29] reported that $10^{7}-10^{8} \mathrm{CFU} / \mathrm{g}$ Lactobacillus effectively suppressed the growth of pathogenic bacteria by decreasing the acidity associated with lactic acid production. In the present study, the adhesion ability of L. acidophilus $(420.00 \pm 28.21)$ and L. brevis $(259.33 \pm 24.03)$ to intestinal epithelial cells was greater than that of the pathogenic bacteria species

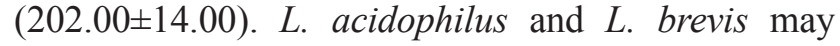

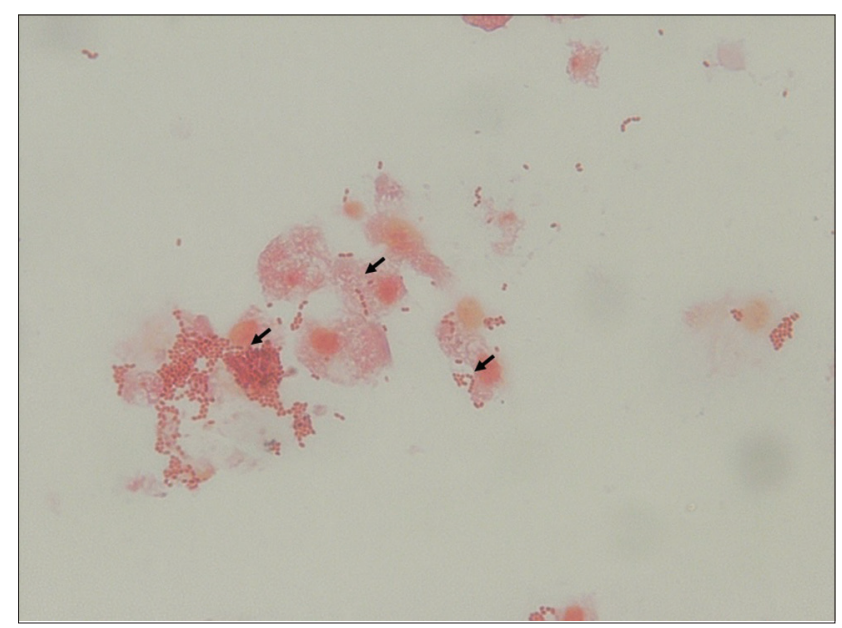

Figure-1: Ability of L. acidophilus (black row) to adhere to intestinal epithelial cells as observed through Gram staining $(1.000 \times)$. 
Table-5: Growth of L. acidophilus, L. brevis, and S. Enteritidis in media enriched with herbal extracts.

\begin{tabular}{lccc}
\hline Herbal combination & \multicolumn{2}{c}{ Optical density $\mathbf{6 5 5} \mathbf{~ n m})$} \\
\cline { 2 - 4 } & L. acidophilus & L. brevis & S. Enteritidis \\
\hline Extract combination 1 & $0.23 \pm 0.01^{\mathrm{ab}}$ & $0.20 \pm 0.00^{\mathrm{b}}$ & $0.11 \pm 0.04^{\mathrm{ab}}$ \\
Extract combination 2 & $0.18 \pm 0.00^{\mathrm{b}}$ & $0.21 \pm 0.01^{\mathrm{ab}}$ & $0.00 \pm 0.00^{\mathrm{a}}$ \\
Positive control & $0.17 \pm 0.00$ & $0.18 \pm 0.02$ & $0.27 \pm 0.01$ \\
Glucose control $^{\mathrm{b}}$ & $0.16 \pm 0.04$ & $0.15 \pm 0.04$ & \\
\hline
\end{tabular}

aSignificant difference $(p<0.05)$ between the herbal extract and positive control, bSignificant difference $(p<0.05)$ between the herbal extract and glucose control. L. acidophilus=Lactobacillus acidophilus, L. Brevis=Lactobacillus brevis, S. Enteritidis=Salmonella Enteritidis

Table-6: Ability of L. acidophilus, L. brevis, and S. Enteritidis to adhere to 50 cells.

\begin{tabular}{lc}
\hline Isolate & Number of bacteria attached to $\mathbf{5 0}$ cells \\
\hline L. acidophilus & $420.00 \pm 28.21$ \\
L. brevis & $259.33 \pm 24.03$ \\
S. Enteritidis & $202.00 \pm 14.00$ \\
\hline
\end{tabular}

L. acidophilus=Lactobacillus acidophilus, L. Brevis=Lactobacillus brevis, S. Enteritidis=Salmonella Enteritidis

prevent pathogens from adhering to the intestinal tract by binding to intestinal mucus. This hypothesis is supported by Ma et al. [30] who reported that the intensive binding of probiotics to intestinal mucus is indicative of low pathogen adhesion to the intestinal tract.

\section{Conclusion}

The combination of herbal and probiotics can adhere to the intestinal tract and may thus be developed as an alternative to AGP.

\section{Authors' Contributions}

VCP: Microbial and herbal preparation, doing all tests, and statistical analysis. WA: Microbial (probiotics and pathogen) analysis. SW: Epithelial cell sampling and adhesion test analysis. AETHW: Main ideas, research design, and analysis. All authors read and approved the final manuscript.

\section{Acknowledgments}

The authors would like to thank the Indonesia Endowment Fund for Education (LPDP), Indonesian Ministry of Finance for the research funding support.

\section{Competing Interests}

The authors declare that they have no competing interests.

\section{Publisher's Note}

Veterinary World remains neutral with regard to jurisdictional claims in published institutional affiliation.

\section{References}

1. Van Den Bogaard, A.E., Ruinsma, N.B. and Tobberingh, E.E.S. (2000) The effect of banning avoparcin on VRE carriage in the Netherlands (Five Abattoirs) and Sweden. J. Antimicrob. Chemother., 46(1): 146-148.

2. Devirgiliis, C., Zinno, P. and Perozzi, G. (2013) Update on antibiotic resistance in foodborne Lactobacillus and Lactobacillus species. Front. Microbiol., 4(301): 1-13.

3. McNamee, S.E., Cunningham, R. and Elliott, C.T. (2013) Simultaneous immunochemical detection of four banned antibiotic growth promoters in raw and cooked poultry tissue. Food Addit. Contam. A, 30(7): 1270-1278.

4. Barton, M.D. (2000) Antibiotic use in animal feed and its impact on human health. Nutr. Res. Rev., 13(2): 1-19.

5. Aidara-Kane, A. (2012) Containment on antimicrobial resistance due to use of antimicrobial agents in animals intended for food: WHO perspective. Rev. Sci. Tech., 31(1): 277-287.

6. Chakraborty, B., Nath, A., Saikia, H. and Sengupta, M. (2014) Bacterial activity of selected medicinal plant against multidrug-resistant bacterial strains from clinical isolates. Asian Pac. J. Trop. Med., 7(1): 435-441.

7. Jin, L.Z., Ho, Y.W., Abdullah, N., Kudo, H. and Jalaludin, S. (1997) Studies on the intestinal microflora of chicken under tropical condition. Asian Austr. J. Anim. Sci., 10(5): 495-504.

8. Quinn, P.J., Markey, B.K., Leonard, F.C., Patrick, E.S.F., Fanning, S. and Hartigan, P.J. (2011) Veterinary Microbiology and Microbial Disease. $2^{\text {nd }}$ ed. John Wiley and Sons Ltd., UK. p301-305, 314-321.

9. Quinn, P.J., Carter, M.E., Markey, B. and Carter, G.R. (2004) Clinical Veterinary Microbiology. Mosby, Toronto. p226-236.

10. Carter, G.R. and Cole, J.R. (1990) Diagnostic Procedures in Veterinary Bacteriology and Mycology. $5^{\text {th }}$ ed. Academic Press. Inc., San Diego California. p23-24.

11. Mukhtar, S. and Ghori, I. (2012) Antibacterial activity of aqueous and ethanolic extracts of garlic, cinnamon, and turmeric against Escherichia coli ATCC 25922 and Bacillus subtilis DSM 3256. Int. J. Appl. Biol. Pharm. Technol., 3(2): 131-136.

12. Bauer, A.W., Kirby, M.W., Sherris, J.C. and Turck, M. (1966) Antibiotic susceptibility testing by a standardized single disk method. Am. J. Clin. Pathol., 45(4): 493-496.

13. Niamsa, N. and Sittiwet, C. (2009) Antimicrobial activity of Curcuma longa aqueous extract. J. Pharmacol. Toxicol., 4(4): 173-177.

14. Clinical and Laboratory Standards Institute M07-A9. (2012) Method for Antimicrobial Susceptibility Tests for Bacteria that Grow Aerobically; Approved Standart. $9^{\text {th }}$ ed. Clinical and Laboratory Standards Institute, USA. p16-19.

15. Clinical and Laboratory Standards Institute M11-A8. (2012) Method for Antimicrobial Susceptibility Testing of Anaerobic Bacteria; Approved Standart. $8^{\text {th }}$ ed. Clinical and Laboratory Standards Institute, USA. p26-34.

16. Wichienchot, S., Jatupornpipat, M. and Rastall, R.A. (2010) Oligosaccharides of pitaya (dragon fruit) flesh and their prebiotic properties. Food Chem., 120(3): 850-857.

17. Son, S., Jeon, H., Yang, S., Lee, N. and Paik, H. (2017) In vitro characterization of Lactobacillus brevis KU15006, an isolate from kimchi, reveals anti-adhesion activity 
against foodborne pathogens and antidiabetic properties. Microb. Pathog., 112: 135-141.

18. Chakraborty, A. and Bhowal, J. (2015) Isolation, identification and analysis of probiotic properties of Lactobacillus spp. From selected regional dairy product. Int. J. Curr. Microbiol. Appl. Sci., 4(6): 621-628.

19. Abdulla, A.A., Abed, T.A. and Saeed, A.M. (2014) Adhesion, auto-aggregation, and hydrophobicity of six Lactobacillus strains. Br. Microbiol. Res. J., 4(6): 381-371.

20. Zhou, Q., Wang, S., Yang, G., Zhao, W. and Li, H.L. (2016) Development and evaluation of herbal formulation with antipathogenic activities and probiotics stimulatory effect. J. Integr. Agric., 15(5): 1103-1111.

21. Zadeh, J.B. and Kor, N.M. (2014) Physiological and pharmaceutical effects of ginger (Zingiber officinale Roscoe) as a valuable medicinal plant. Eur. J. Exp. Biol., 4(1): 87-90.

22. Hansel, R. (1980) Pharmazeutische Biology. SpringerVerlag, Berlin.

23. Oon, S.F., Nallappan, M., Tee, T.T., Shohaimi, S., Kassim, N.K., Sa'ariwijaya, M.S. and Chaeh, Y.H. (2015) Xanthorrhizol: A review of its pharmacological activities and anticancer properties. Cancer Cell Int., 15(1): 1-15.

24. Handrianto, P. (2016) Uji antibakteri ekstrak jahe merah Zingiber officinale var. Rubrum terhadap
Staphylococcus aureus dan Escherichia coli.J. Res. Technol., 2(1): 1-4.

25. Natta, L., Orapin, K., Krittika, N. and Pantip, B. (2008) Essential oil from five Zingiberaceae for anti food-borne bacteria. Int. Food Res. J., 15(3): 337-346.

26. Halim, M.R.A., Tan, M.S.M., Ismail, S. and Mahmud, R. (2012) Standardization and phytochemical studies of Curcuma xanthorrhiza Roxb. Int. J. Pharm. Pharm. Sci., 4(3): 606-610.

27. Molan, A.L., Flanagan, J., Wei, W. and Moughan, P.J. (2009) Selenium containing green tea has higher antioxidant and prebiotic activities than regular green tea. Food Chem., 114(2009): 820-835.

28. Rahminiwati, M., Rahmatullah, S., Batubara, I. and Achmadi, S.S. (2014) Potensi ekstrak rimpang kunyit sebagai prebiotik pemacu pertumbuhan Lactobacillus plantarum secara in vitro. J. Ilmu Kefarmasian Indones., 12(1): 37-42.

29. Fuller, R. (1989) Probiotic in man and animals. J. Appl. Bacteriol., 66(5): 365-378.

30. Ma, Y.L., Guo, T., Xu, Z.R., You, P. and Ma, J.F. (2006) Effect of Lactobacillus isolates on the adhesion of pathogens to chicken intestinal mucus in vitro. J. Compil. Appl. Microbiol., 42(4): 369-374. 